\title{
Menuju Effisiensi Produksi Mesin Scraper untuk Pekerjaan Pemindahan Tanah
}

\author{
Oleh : Balya Umar
}

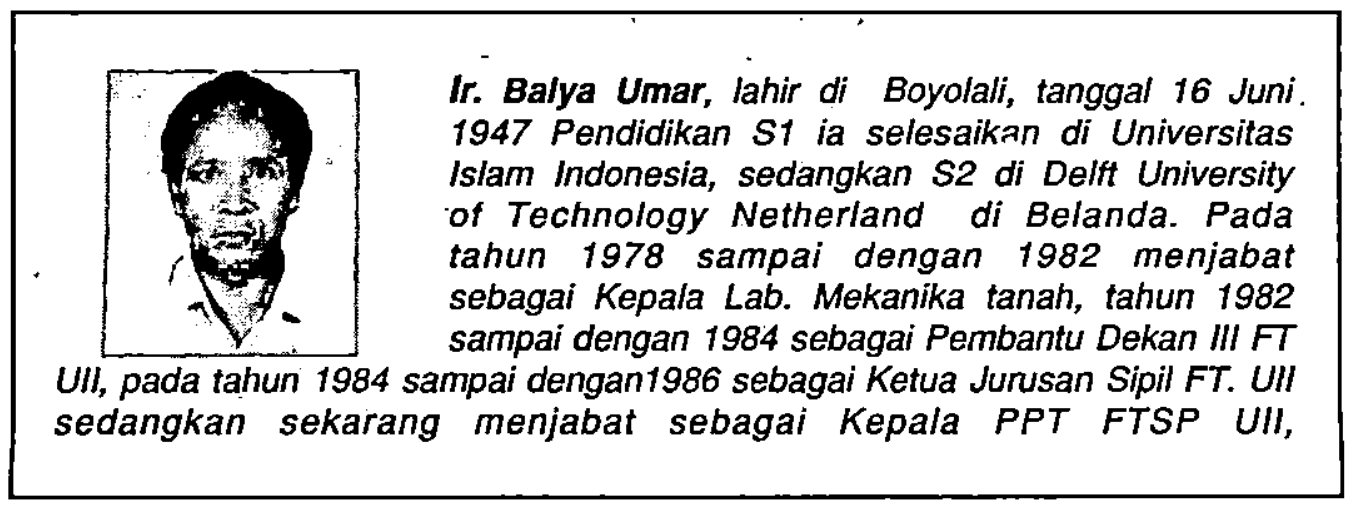

Pengantar

Masih ada teknisi maupun praktisi yang kurang memahami bagaimana mengefisiensikan hasil kerja mesin scraper untuk keperluan pekerjaan pemindahan tanah dikarenakan kurangnya pemahaman ini dapat mengakibatkan kurangnya/tidak tepatnya penggunaan mesin scraper memproduksi hasil kerjanya. Disamping kurang optimalnya hasil produksi, bahkan kadang-kadang dapat menimbulkan cepat rusaknya ataupun terlalu banyak beaya pemeliharaan alat tersebut. Untuk itu perlu adanya pengkajian/pemahaman bagaimana supaya mesin scraper tersebut dapat berproduksi seoptimal mungkin, sehingga tidak menimbulkan/mengakibatkan beaya operasional maupun pemeliharaan menjadi melonjak.

\section{Pendahuluan.}

Pada setiap pekerjaan tanah, selalu dihadapkan pada persoalan bagaimana memindahkan tanah pada waktu yang telah ditentukan dengan beaya yang seefisien mungkin.

Untukmencapai tujuantersebut, halhal yang sangat fundamental adalah apakah seseorang itu (dalam mengatur) tahu benar, tentang prinsip-prinsip teori pekerjaan tanah dan pengetrapannya dalam setiap pekerjaan yang dihadapi. Hal-hal yang penting untuk diketahui adalah yang menyangkut PRODUKSI SUATU MESIN serta BEAYA YANG DITIMBULKANNYA.

Produksi mesin.

Suatumesinumumnya direncanakan untuk suatu pekerjaán dalam kondisi teertentu. Penggunaan suatu mesin untuk suatu pekerjaansupaya optimal produksinya harus diketahui tenaga yang diperlukan untuk suatu pekerjaan disesuaikan dengan tenaga yang tersedia dari mesin tersebut 
Kebutuhan tenaga.

Kebutuhan tenaga adalah tenaga yang dibutuhkan untuk mesin sewaktu bergerak menggaruk permukaan tanah, untuk memotong sepanjang tanah yang dipotong/digali. Faktor yang berpengaruh adalah "rolling resisitance" dan "grade resistance". Tenaga yang diperlukan untuk keperluan diatas sama untuk mengatasi "rolling resisitance" ditambah "grade resistance".. Keduanya diukurdalam "pounds/ kg" baikuntuk menarik ataupunmendorong ("pull" atau " push")

Rolling resistance adalah kekuatan yang diperlukan untuk menggerakkan roda (untuk mengatasi tahanan roda terhadap tanah). Kekuatan ini yang diperlukan sebelum roda mulai bergerak.

Yang berpengaruh pada rolling resistance adalah :

- intemal friction

- kelenturan pada ban (tire flexing)

- tekanan ban pada jalan akibat berat traktor

Yang dimaksud "intemal friction" yaitu gesekan yang ditimbulkan dari mesin sampai roda. Hal ini disebabkan karena pengaruh komponen-komponen mekanis yang bergerak, sehingga menimbulkan gesekan.
Kelenturan padaban akan menaikkan tekananpada pergerakan. Hal ini tergantung pada besarnya tekanan, rancangan dari bentuk ban dan kondisi permukaan jalan yang dilalui.

Yang dimaksud berat kendaraan (traktor) adalah berat dalam kondisi kosong dan ditambah beban yang diangkut. Dalam perhitungan pemindahan/pengangkutan pekerjaan tanah ini efek dari "intemal friction" dan "tire flexing" dapat dianggap konstan. Oleh pabrik diperhitungkan sebesar $2 \%$ dari berat kendaraan (Gross Vehicle Weight (GVW) ) 2\% GVW setara dengan 40bs/ton. Dengan kata lain, 40 punds/ton ('gaya tarik atau dorong) yang diperlukan untuk bergerak traktor yang beroda ban karet pada permukaan yang keras, halus dan rata. Bila pada ban suatu traktor mengalami penetrasi 1 inc pada suatu muka tanah, maka akibat penetrasi ini rolling resistance (berdasarpengalaman) akan diperlukan sebesar $30 \mathrm{lbs} / \mathrm{ton}$. Maka bilà traktor bergerak pada tanah yang menyebabkan roda mengalami penetrasi 2 inch. Maka rolling resistance yang diperlukan $=40+(2 \times 30)=100 \mathrm{lbs} / \mathrm{ton}$.

Berikut ini adalah besamya faktor rolling resistance (RRF) yang diterapkan dari pabrik $(20 \mathrm{lbs} /$ ton $=1 \%)$. 
Tabel 1.1 Faktor Rolling Resistance (RRF)

\begin{tabular}{|l|c|c|}
\hline Kondisi permukaan jalan/tanah & $\mathrm{lbs} / \mathrm{ton}$ & $\mathrm{kg} / \mathrm{ton}$ \\
\hline 1. Këras, rata, terstabilisasi, tak mengalami penetrasi bila & & \\
dilewati & 40 & 20 \\
2. Kompak, rata, berdebu, ban agak melentur, sedikit basah. & 65 & 35 \\
3. Butir-buttir lepas & 90 & 45 \\
4. Berdebu, bergelombang/berlobang membentuk seperti & & \\
parit (rutted) 1" - 2" penetrasi ban ke dalam tanah. & 100 & 50 \\
5. Rutted dirth roadway, lunak, tak ada pemeliharaan. 4" - 6" & &. \\
ban masuk, ke dalam. & 150 & 75 \\
6. Pasir / kerikil lepas. & 200 & 100 \\
7. Lunak, berlumpur. rutted roadway, tak terpelihara. & $200-400$ & $100-200$ \\
\hline
\end{tabular}

Sumber : Handbook of Earthmoving : Caterpillar Tractor Co. 1981.

Bila faktor tekanan gelinding (rolling resistance fảctor $=$ RRF) tclah diketahui, dan bcrat traktor total telah diketahui, maka rolling resistance (RR) bisa ditentukan. Sebagai contoh : Bila GVW $=110$ ton dan besamya $R R F=65 \mathrm{lbs} / \mathrm{ton}$, maka besamya $\mathrm{RR}=65 \mathrm{lbs} /$ ton $\times 110$ ton $=7150 \mathrm{lbs}$. "Grade resistance" adalah kekuatan/daya untuk mengatasi berat sendiri waktu traktor mendaki bukit. Kelandaian dinyatakan dalam prosen (\%). Pada pendakian, daya tersebut disebut "grade resistance"', sedang pada penurunan disebut "grade assistance" yang mempunyai pengaruh membantu mendorong. Setiap 1\%kenaikan/penurunan lereng akan mengurangi/menambah daya sebesar $20 \mathrm{lbs} / \mathrm{ton}$ GVW

$\mathrm{GR} / \mathrm{GA}=\mathrm{GVW} * \%$ naik/turun $* 20 \mathrm{lbs} / \mathrm{ton}$ Sebagai contoh :

Traktor scaper dengan berat total 100 ton berjalan pada tanjakan sebesar $5 \%$, maka besarnya grade resistance (GR) adalah : $\mathrm{GR}=100 * 5 * 20=10.000 \mathrm{lb}$.

Apabila traktor bekerja pada daerah datar, rolling resistance hanya diperlukan untuk mengatasi beratnya saja. Tetapi bila 
bekerja pada daerah tanjakan, selain berat juga diperhitungkan terhadap tanjakan ( $R$ $=\mathrm{RR}+\mathrm{GR}$ ). Sebaliknya pada daerah penurunan, jumlah resistance yang diperlukan sama dengan rolling resistance dikurangi pengaruh penurunan (grade assistance). Disini yang perlu mendapat perhatian adalah kondisi rem dan permukaan ban.

\section{Tanjakan Effektif}

Faktor yang dominan untuk menentukan besamya tenaga pada tanjakan adalah "rolling resistance" dan "Grade resistance". Tenaga minimum yang dibutuhkan adalah sama dengan " total resistance" yang terjadi. Total resistance dapat diekspresikan dalam bentuk persen, maka inilah yang dapat disebut juga besarnya tanjakan effektif (EG)

$\mathrm{EG}=\mathrm{RR}(\%)+\mathrm{GR}(\%)$

Tanjakan effektif ini didapatkan dengan membandingkan RRF (rolling resistance factor) dengan presentanse yang berkaitan dengan kebutuhan RR sebesar $20 \mathrm{lbs} / \mathrm{ton}$ untuk tanjakan sebesar $1 \%$. Tanjakan effektif(EG) dibutuhkanuntukmenentukan besamya rimpul, performance dari rem, \& travel time. Berikut ini adalah suatu ilustrasi perhitungan tanjakan effektif.

Wheel tractor-scraper berjalan pada suatu jalan yang cukup kompak, halus dan menanjak sebesar $3 \% \mathrm{RRF}=60 \mathrm{lbs} / \mathrm{ton}$. Berapa besamya tanjakan effektif yang masih bisa dilaluinya ?Kebutuhan RR sebesar $20 \mathrm{lbs} /$ ton adalah untuk mengatasi tanjakan sebesar $1 \%$, maka disini tanjakan yang masih dapat diatasi adalah sebesar $60 /$ $20=3 \%$. Oleh karena itu tanjakan effektif yang masih terjangkau adalah " $\mathrm{EG}=3 \%+$ $3 \%=6 \%$

\section{Tersedianya Tenaga}

Bila kebutuhan tenaga sudah terhitung, maka jenis mesin yang memenuhi kebutuhan tenaga tersebut bisa ditentukan. disini ada dua faktor untuk menentukan jenis mesin yang dibutuhkan berkaitan dengan tenaga yang dibutuhkan/yang harus disediakan yaitu " Horse power " dan "speed"

Hubungan antara " Horse power" (HP) dan "Speed" (V) adalah : HP = Gaya tarik (pounds) * speed atau HP = gaya * kecepatan Bila HP suatu mesin itu konstan, maka besamya gaya tarik (pounds) akan bervariasi/berubah sejalan dengan perubahan kecepatan, kecepatan tinggi, akan mengakibatkan daya tarik (pounds pull) rendah, begitu pula sebaliknya. Gambar grafik (gambar 1.1) berikut ini menunjukkan hubungan antara kecepatan dan daya tarik (Drawbar pull) pada masingmasing gigi. 
kilograms pounds

(in 1000s) (in 1000s)

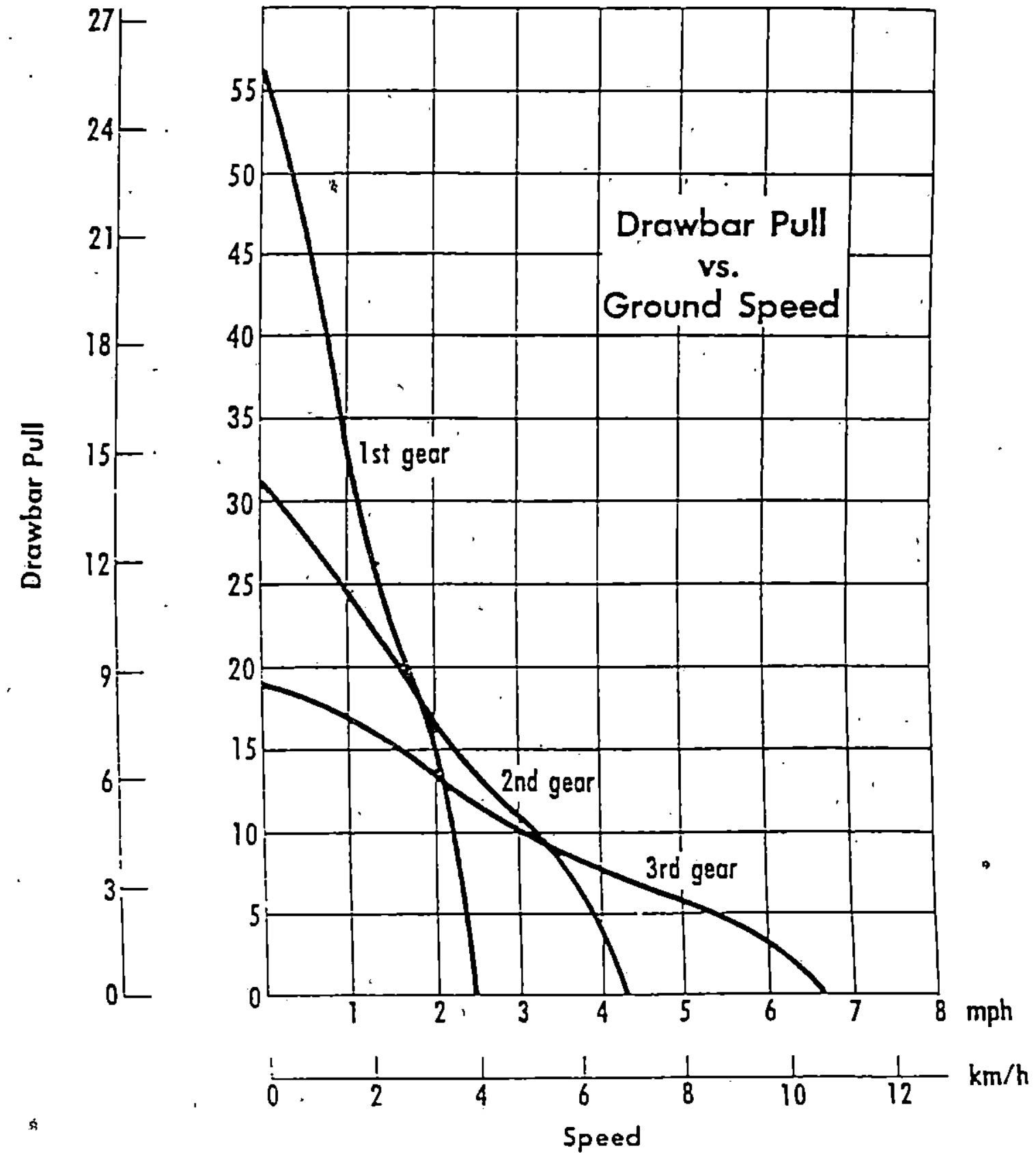

Gambar 1.1 Hubunqan antara kecepatan dan qaya tarik (Drawbar puli) 
Daya Berguna (Power Usable)

" Power usable " ini tergantung dari kondisi "traksinya dan "altitude" (ketinggian tempat dari "Sea level") Traksi adalah kejadian gesekan (cengkeraman) antara roda ataupun rantai dengan permukaan ajalan yang dilalui. Hal ini besarnya bermacam-macam, tergantung berat dari beban yang dilimpahkan pada roda penggerak atau rantai dan tipe dari permukaan jalan yang dilalui. Maksimum dayà yang bisa disediakan adalah dibatasi oleh berat yang dilimpahkan pada roda/ rantai penggerak. Daya tarik suatu mesin tidak dapat melebihi besamya berat beban yang dilimpahkan pada roda penggeraknya. Misal suatu mesin traktor- sciper sudah direncanakan besamya beban pada roda penggerak $=55 \%$ berat seluruhnya $(\mathrm{GVW})$, maka daya yang dapat digunakan maksimum sebesar $55 \%$ dari GVW tidak semua tenaga secara teoritis dapat digunakan, karena adanya faktor pengurang tenaga. Maka secara effektif besamya tenaga yang bisa digunakan harus dikalikan dengan koeffisen traksi .

Koeffisien traksi adalah rasio jumlah tenaga tarik (pounds pull) dari mesin sebelum terjadi slip terhadap berat total yang ada pada roda gerak. Sebagai contoh : Bila suatu mesin beban pada roda gerak 80.000 pounds, roda mulai slip bila dikerjakan tarikan sebesar 40.000 pounds, maka besamya koeffisien traksi

$$
=\frac{40.000}{80.000}=0,5
$$

Bila daya yang diperlukan melebihi 40.000 pounds, pada roda akan terjadi slip. Berikut ini daftar besamya koeffisien traksi

Tabel 1.2 Besamya koeffisien traksi

\begin{tabular}{|c|c|c|c|}
\hline $\begin{array}{c}\text { Kondisi } \\
\text { permukaan jalan }\end{array}$ & & $\begin{array}{l}\text { Rubber tires } \\
\text { (ban karet) }\end{array}$ & $\begin{array}{l}\text { Tracks } \\
\text { (rantai) }\end{array}$ \\
\hline 1. Concrete (beton) & & 0,90 & 0,45 \\
\hline 2. Clayloam (dry) & & 0,55 & 0,90 \\
\hline 3. Clayloam (wet) & & 0,45 & 0,70 \\
\hline 4. Ruttedclayloam & & 0,40 & 0,70 \\
\hline 5. Drysand & & 0,20 & 0,30 \\
\hline 6. Wetsand & . & 0,40 & 0,50 \\
\hline 7. Quarrypit & - & 0,65 & 0,55 \\
\hline 8. Gravelroad (loose) & ' & 0,36 & 0,50 \\
\hline 9. PackedSnow & & 0,20 & 0,25 \\
\hline 10. Ice & & 0,12 & 0,12 \\
\hline 11: Semi skeleton shoes & & - & 0,27 \\
\hline 12. Finm Earth & & 0,55 & 0,90 \\
\hline 13. Loose Earth & & 0,45 & 0,60 \\
\hline 14. Coal, stockpiled & & 0,45 & 0,60 \\
\hline
\end{tabular}


Dengan menggunakan koeffisien traksi tersebut dan berat beban yang ada pada roda gerak, maka tenaga yang digunakan (lbs) dapat ditentukan.

$\mathbf{P}=\mathbf{f} * \mathbf{w}$

$\mathrm{P}=$ tenaga yang digunakan (lbs)

$\mathrm{f}=$ koeffisien traksi

$\mathbf{w}=$ berat/beban roda gerak (lbs)

Contoh berikut menggambarkan berapa tenaga yang digunakan " untuk menggerakkan sebuah traktor bila data lainya sudah diketahui terlebih dahulu. Misal suatu traktor scraper beroda rantai yang berjalan pada tanah lempung yang basah, beratnya $=50.000 \mathrm{lbs}$ maka tenaga yang digunakan. $P=0,70 * 50.000=35.000$ lbs

Perlu diketahui bahwa ketinggian tempat kerja dari permukaan air laut (altitude) akan mempengaruhi besarnya tenaga yang dapat digunakan. Pada tempat yang lebih tinggi (altitude membesar), udara berkurang kecepatannya. Tempat yang berketinggian diatas 300 feet, kerapatan udara menurun, sehingga menyebabkan menununnya kekuatan (horse power) dari suatu mesin. Makin tinggi suatu tempat dari muka air laut, makin berkurang output dari tenaga mesin. Setiap 1000 feet diatas 3000 feet tenaga berkurang sebesar $3 \%$. Misal suatu traktor bekerja pada elevasi 5000 feet tenaga menurun sebesar $6 \%$.

Estimasi Produksi suatu Pekerjaan

Banyak faktor yang mempengaruhi suatu pekerjaan.Suatu produksi pekerjaan (tanah) terutama yang sangat berpenganuh adalah :

1. material yang dikerjakan

2. waktu kerja

3. effisiensi

Untuk mengetahui berapalamaharus bekerja seseorang harus lebih dahulu mengetahui banyaknya $\left(\mathrm{m}^{3}\right)$ material (tanah) yang harus dikerjakan. Atau sebaliknya, bila waktu yang telah ditentukan serta jumlah volume pekerjaan yang harus dilakukan, maka berapa seharusnya produksi yang harus dicapai dalam satuan. waktu tertentu.

Sebagai contoh adalah sebagai berikut :

Seseorang diberi waktu 4 minggu untukmemindahkan tanah sebesar 100.000 $\mathrm{m}^{3}$. Dia harus bekerja 10 jam tiap hari dan 6 hari dalam 1 ( satu) minggu, Ini berarti bahwa :

Dalam 4 minggu harus bekerja 4 * 6 hari $=$ 24 hari

Dalam 24 hari harus bekerja $24 * 10$ jam $=$ 240 jam

Dalam waktu tersebut dia harus bisa berproduksi 100.000

$240 \mathrm{~m}^{3} / \mathrm{jam}=416,67 \mathrm{~m}^{3} / \mathrm{jam}$

Cara yang terbaik untuk mengerjakan ini adalah harus tahu kemampuan bekerja alat. Kalau suatu alat (traktor) akan dipekerjakan di lapangan, maka ada 4 fungsi utama yang harus dikerjakan, yaitu :

1: memuat (load)

2. mengangkut (haul)

3. menumpahkan (dump), dan

4. kembali (return)

\section{Cycle time}

Pada suatu pekerjaan pemindahan tanah, kerja dari suatu mesin berkaitan dengan perputaran pekerjaan tertentu, yaitu :memuat, mengangkut, menumpahkan dan kembali ke tempat semula atau variasi dari 4 hal tersebut. "Cycle Time" adalah jumlah waktu yang diperlukan untuk memenuhi putaran operasi alat tersebut. Cycle time ini diperlukan untuk mengestimasi produski. 
Untuk memperbesar hasil produksi, salah satu usaha adalahmemperkecil "cycle time" yang diperlukan.

"Cycle time" terdiri dari dua kategori, yaitu Fixed time (waktu tetap), dan Variable time (waktu tidak tetap)

Fixed time adalah waktu yang digunakan untuk memuat menumpahkan (loding and dumping). Fixed time ini umumnya adalah tetap, sedang variable time adalah waktu yang diperlukan untuk mengangkut ataupun kembali ke tempat memuat. Untuk memperbanyak produksi, maka usaha yang dilakukan adalah dengan memperkecil cyle time.

\section{Memperkecil Fixed Time}

Usaha untuk memperkecil "fixed time" diantaranya adalah :

1. Bila memungkinkan letak borrow pits" (tempat pengambilan material) lebih tinggi dari pada alat traktor yang tersedia, sehingga pada waktu memuat akanlebih mudah.

2. Bila memungkinkan dihilangkan waktu tunggu dengan jalan memperhitungkan waktu muat dan waktu mengangkut hingga kembalinya.

3. Traktor pendorong pada borrow pits hendaknya dilengkapi dengan "nippers", terutama pada alat pemuat (loading) sehingga selain memuat sekaligus menggemburkan tanah yang dimuat.

\section{Memperkecil Variable time}

Usaha memperkecil variable time dapat diusahakan antara lain dengan :

1. Menentukan tata letak (layout) jalan angkutsecara tepatkadang-kadang jalan yang lurus yang menghubungkan antara. dua tempat belum tentu menguntungkan
: misal kondisinya becek, dll. Ada kalanya akan lebih baik melalui rute melingkar suatu bukit tapi jalannya cukup keras.

2. Menjaga jalan angkut supaya tetap baik secara kontinyu. Dengan menggunakan suatu alat untuk memelihara jalan angkut, beayanya akan lebih murah dari pada beaya produksi bila tanpa adanya perawatan.

\section{Material}

Dengan mengetahui sifat-sifat dari material yang akan diangkut/dipindahkan, maka dapatlah ditentukan "kemampuan memuat" suatu alat terhadap material tersebut . Sifat kemampuan memuat suatu alat dapat dijelaskan dengan melihat karakteristik suatu material. Bila material itu mudah digali dan dimuat, hal ini dapat dikatakan derajat kemampuan memuatnya cukup tinggi. Begitu pula sebaliknya, sehingga dalam memilih suatu alat yang akan dipakai harus diketahui secara pasti terlebih dahulu sifat-sifat fisik dari material tersebut. Secara garis besar material yang dimuat/digali/diangkut terdiri dari tiga macam jenis, yaitu :

1. material batuan (rock materials)

2. material tanah (soil materials),dan

3. material tanah berbatu (rock-soil materials)

Perlu dikethui, besamya kadar air yang terkandung padamaterial akan berpenganuh pada mudah/tidaknya dikerjakan, dan berat/ ringannya untuk diangkut. Material yang dipindahkanmempunyai 3 sifat utama yang harus diperhatikan, yaitu :

1. berat (weight)

2. pengembangan (swell), dan

3. sifat bila dipadatkan (compactability) 
Sifat - sifat material akan berpengaruh tehadap volume material yang dianngkut, kecepatan pengangkutan, dan gaya yang diperlukan untuk mengangkut. Volume material dapat diukur dari 2 tinjauan, yaitu :

1. alami (bank0, dan

2. material lepas (loose).

bank : $1 \mathrm{~m}^{3}$ material alami (bank materials) yaitu besamya volume $1 \mathrm{~m}^{3}$ dalam kondisi asli (bank) Loose : $1 \mathrm{~m}^{3}$ material lepas (loose) yaitu besarnya volume $1 \mathrm{~m}^{3}$ dalam kondisi lepas (loose)

Dari2 (dua)kondisi material tersebut, maka pengembangan (sweel) adalah kenaikan volume material kalau material tersebut dipindahkan dalam kondisi alami menjadi kondisi lepas (loose). Hal ini diekspresikankedalam prosentase terhadap kondisi alami. sebagai contoh, bila suatu tanah mempunyai nilai swell $40 \%$, maka bila tanah itu digali, volumenyā menjadi i $1,40 *$ volume aslinya $\left(1 \mathrm{~m}^{*}\right.$ tanah asli $=$ $1.40 \mathrm{~m}^{3}$ setelah digali (loose)

Selainnilai swell, kondisi perubahan tanah dari alami menjadi lepas (loos̄e) juga dapat dilihat dari nilai "load factor " : Load factor" adalah prosentase penurunan berat volume darikondisi alami (bank) kekondisi lepas (loose)

Load factor (LF) $=\frac{\left.t / m^{3} \text { (loose } / \text { lepas }\right)}{t / m^{3} \text { (bank / alami) }}$

$$
\% \text { Swell }=\left(\frac{1}{\mathrm{LF}}-1\right) * 100 \%
$$

Misal tanah dalam kondisi loose $=44 \mathrm{~m} 3$, $\mathrm{LF}=0,82$, maka dalam kondisi alami volumenya $=0,82 * 44=36 \mathrm{~m}^{3}$

Prosentase swell $=\left(\frac{1}{0,82}-1\right) * 100 \%=22 \%$.atau

$$
\text { swell }=\left(\frac{44-36}{36}\right) * 100 \%=22 \%
$$

Dalam pekerjaan pemindahan tanah, selain kondisi alami (bank) lepas (loose) ada juga tanah dalam kondisi menyusut volumenya karena proses pemadatan (shrink). Oleh karena itu bila tanah misalnya dalam kondisi alami $\left(1 \mathrm{~m}^{3}\right)$ mempunyai faktor swell (30\%), tanah lepasnya (loose) $=1,30 \mathrm{~m}^{3}$ dan bila mempunyai faktor susut (shrink) sebesar $25 \%$, maka volume padatnya $=0,75 \mathrm{~m}^{3}$. Besarnya volume tersebut umumnya digunakan dalam menghitung besamya beaya/besamya produksi mesin yang akan diperlukan/dicapai.

\section{Faktor Effisiensi}

Keberhasilan suatu pekerjaan tergantung beberapa faktor yang saling menunjang sehingga timbullahusaha untuk memperbesar suatu effisiensi. Ketika mengestimasi suatu produksi, baik untuk sebuah mesin ataupun suatu armada mesin hasilnya didasarkan terhadap $100 \%$ effisiensi (sebagai pembanding). Tetapi perlu diingat, suatuperusahaan akan bekerja dengan orang, cuaca dan mesin yang komponen-komponennya membutuhkan penggantian serta carakerja yang dilakukan.

\section{Faktor Effisiensi Kerja}

Effisiensi kerja ini adalah elemen produksi yang sangat komplek untuk mengestimasi suatu produksi. Hal ini dipengaruhi kemampuan operator, banyaknya perbaikan-perbaikan mesin, kondisi keaktifan kerja operator serta layout tempat kerja. Besamya effisiensi kerja dapat dipakai seperti tabel berikut ini. 
Tabel 1.3 Faktor effisiensi kerja.

\begin{tabular}{|l|c|c|c|}
\hline Waktu & Alat & $\begin{array}{c}\text { Jam kerja } \\
\text { (menit/jam) }\end{array}$ & Faktor \\
\hline Siang & Track type tractor & 50 & 0.83 \\
cerah & whell type tractor & 45 & 0.75 \\
\hline Malam & Track type tractor & 45 & 0,75 \\
cerah & whell type tractor & 40 & 0,67 \\
\hline
\end{tabular}

Faktor $=$ jumlah menit kerja/jam

Sebagai contoh bila produksi traktor $=50$ $\mathrm{m}^{3} / \mathrm{jam}$ dan besamya faktor effisiensi $=$ 0,75 maka hasil produksi/jam adalah sebesar $0,75 * 50=37,50 \mathrm{~m}^{3}$.

\section{Faktor Koreksi.}

Faktor ini digunakan untuk memodifikasi dari estimasi produksi untuk menentukan pekerjaan yang sudah tertentu pada suatu kondisi setempat. Faktor-faktor ini bervariasi pada setiap tipe mesin yang digunakan pada suatu pekerjaan. Umumnya setiap mesin yang dikeluarkan suatu pabrik sudah dilengkapi catatan mengenai faktorfaktor ini. Namun bila tak ada, dapat didasarkan pada suatu pengalaman dan kondisi setempat.

\section{Produksi Mesin}

Untuk memperkirakan/menghitung produksi suatu mesin, langkah-langkah berikut perlu diperhatikan.

1. Langkah pertama yaitu menentukan kapasitas mesin yang digunakandengan ditunjukkan volumemuat setiapputaran.
2. Menghitung waktu putar (cycle time) yang terdiri dari waktu muat, angkut, menumpahkan dan kembali.

3. Setelah mengetahui berapa kali putaran produksinya dalam waktu 1 (satu) jam, maka bisa diketahui produksi mesin itu setiap jamnya. Produksi nettonya tergantung faktor-faktor effisiensi yang mempengaruhinya.

Perlu diingat faktor-faktor lain yang juga sangat berpengaruh pada suatu produksi, misal kemampuan operator, metode/cara berproduksi, cuaca, lalu-lintas, dan lainlain.

\section{Wheel Tractor-Scrapers}

Untuk mengestiamsi produksi jenis traktor ini, langkah-langkah berikut perlu diketahui.

1. Kapasitas muat.

Perlu diketahui- terlebih dahulu kapasitasmuat rata-rata dari mesin tersebut. Sebagai contoh suatu Scraper bisa mengangkut/memuat tanahlempung kering sebanyak 44 cubicyards (loose), sedangkan 
besarnya "load factor" $=0,81$, maka tanah tersebut dalam kondisi alam (bank) volumenya $=0,81 * 44=35,6$ bcy (bank cubic yards).

2. Cycle time.

Untuk menentukan "cycle time", empat bagian yang menentukan besamya cycle time perlu diperhatikan, yaitu :

a. Waktu muat (load time)

Untuk Wheel traktor scraper berkisar sekitar 0,6 - 1,0 menit tergantung kapasitas bowl, ukuran dari pusher; kondisi kerja, single atau tandem power.

b. Waktu buang (dump time)

Waktu ini berkisar antara 0,6-0,8 menit.

c. Waktu angkut (haul time)
Hal ini tergantung pada beban yang dibawa, tersedianya tenaga mesin, kondisi permukaan jalan dan jarak angkut.

d. Waktu kembali (return time)

Waktu ini sebagian besar faktor yang berpengaruh adalah kondisi jalan, kendaraan dan operatomya.

Untuk memperhitungkan "travel time". CaterpilarPerformance Hand Booktelah menyediakan grafik guna keperluan menentukan berapa lama waktu yang dibutuhkan baik waktu berangkat (dalam kondisi penuh muatan) ataupun kembali dalam kondisi kosong (empty) seperti gambar berikut ini.

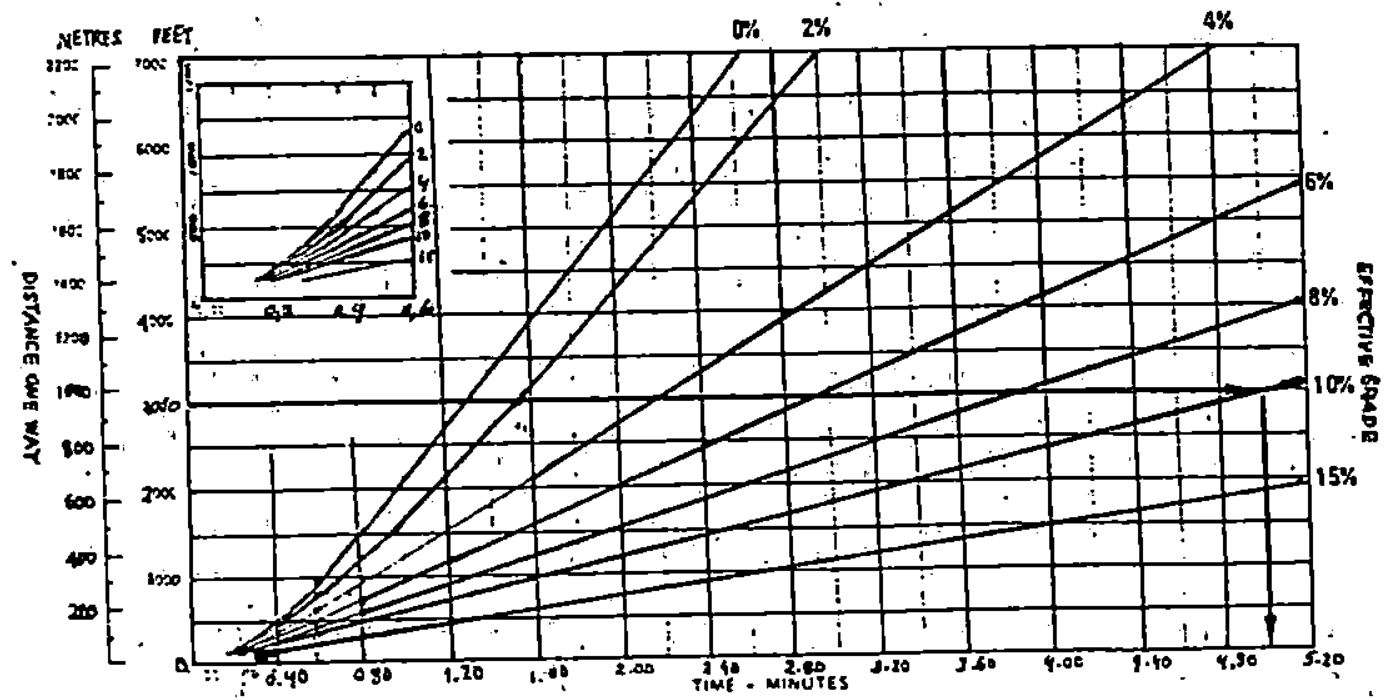




\section{DISTANCE VS TIME - EMPTY}

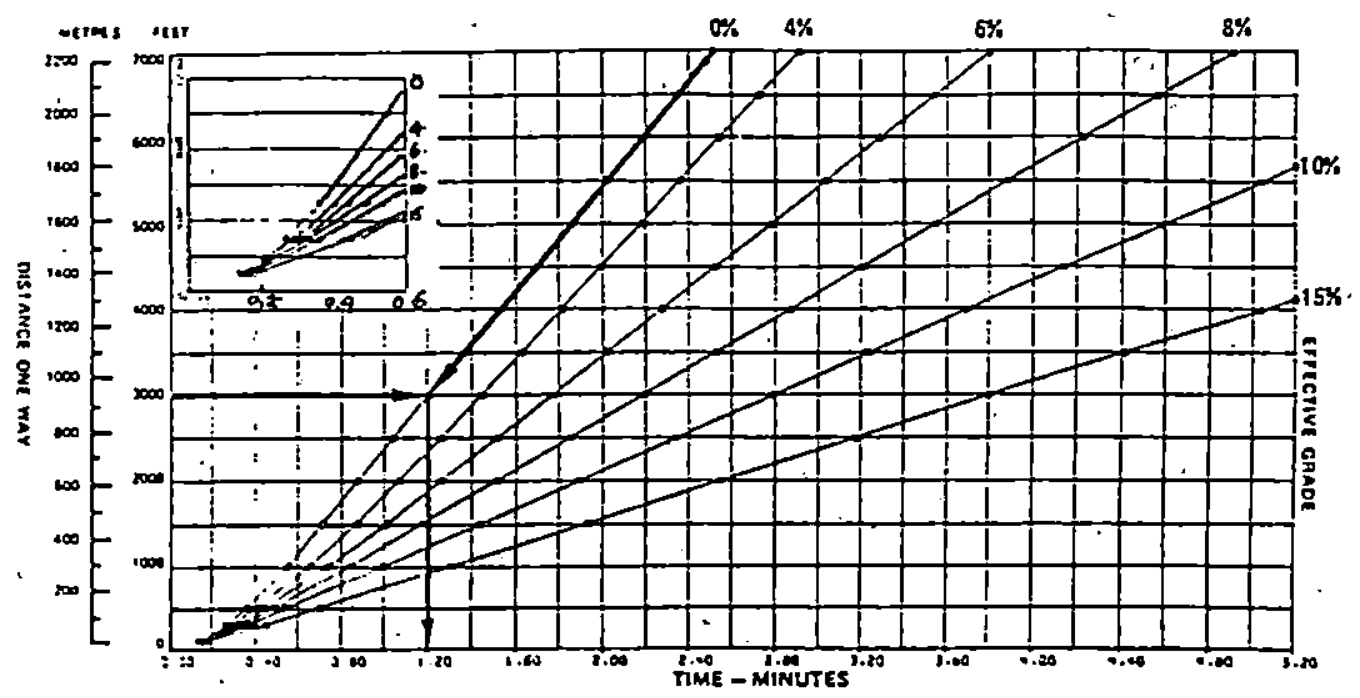

Gambar 1.2 Grafik hubunqan antara waktu yang dibutuhkan denqan jarak temput yang dipengaruhi besarnya lereng (kondisi termuati \& kosonq).

Pengereman dan atau Perlambatan.

Bila Tractor Scrapper berjalan pada jalan yangmenurun, untuk keselamatannya perlu memperlambat/mengerem perjalanannya. Kecepatan operasinya dibatasi sedemikian sehingga kemampuan mesinnya tak terlambat. Hal ini akan berpengaruh pada travel time. Kecepatan maksimum yang masih termasuk katagori aman padajalan yang menurun dapat dibaca pada gambar grafik beriku ini. 


\section{GROSS WEIGHT}

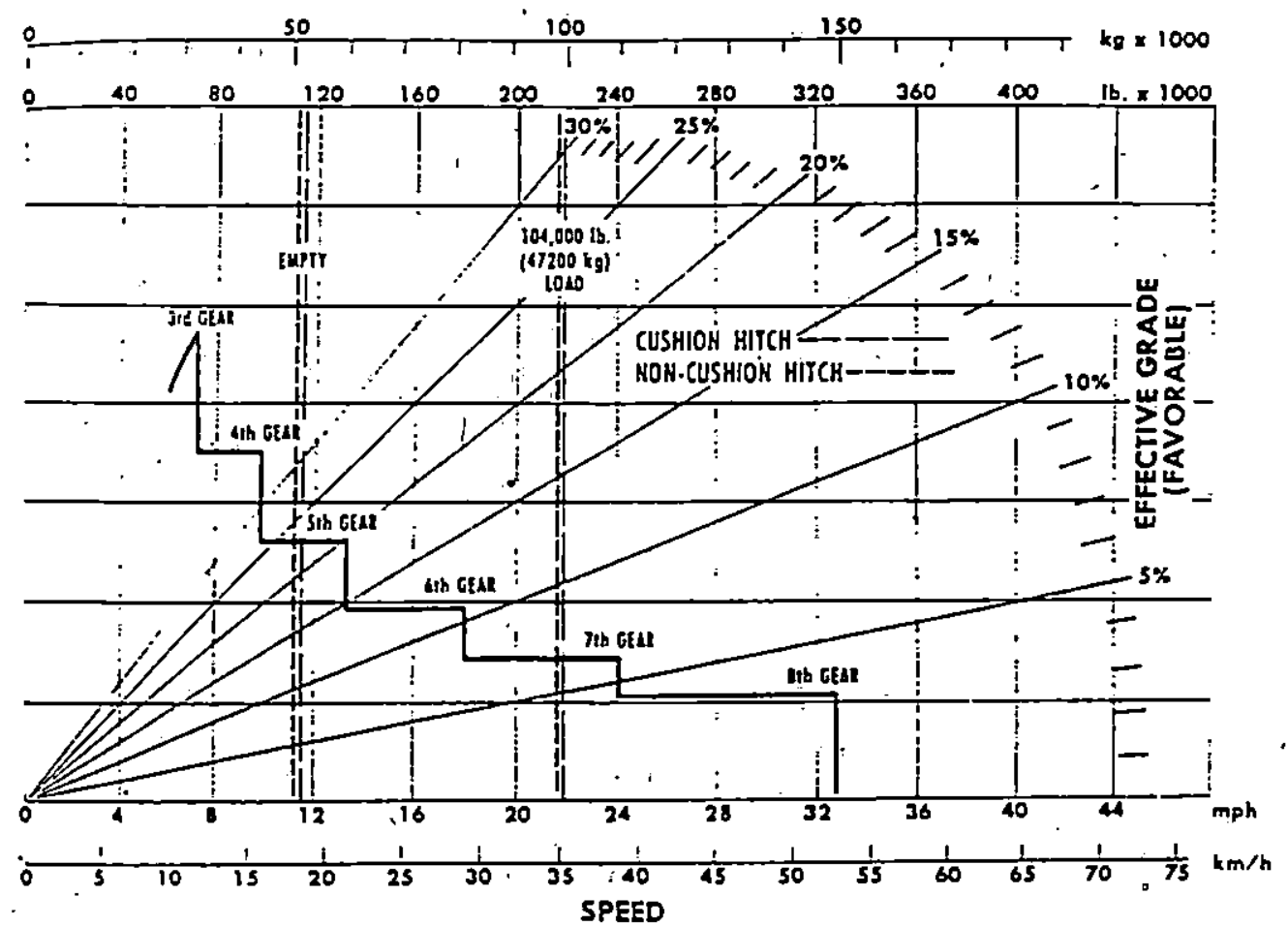

Gambar 1.3 Grafik hubunqan antara kecepatan aman pada waktu termuati/kosong pada jalan yang menurun.

Caranya yaitu dengan menarik garis kebawah dari data berat traktor sampai memotong garis yang menunjukkan \% lereng. Kemudian dari sini ditarik garis horizontal sampai memotong batas maksimal gigi yang bisa dicapai. Seterusnya ditarik garis kebawah, maka didapatlah kecepatan maksimum yang masih amian.

\section{Kesimpulan}

Dari uraian-uraian di atas dapatlah diambil kesimpulan bahwa untuk mencapai effisiensi kerja dari mesin scraper perlu diketahui :

1. Karakteristik dari mesin scraper yang digunakan yang meliputi tenaga yang tersedia dan tenaga yang dibutuhkan.

2. Kondisi medan yang akan dikerjakan, meliputi tanjakan/penurunannya, jenis tanah yang akan dikerjakan besertasifatsifatnya.

3. Kemampuan operator mengoperasikan peralatan dan waktu kerja (malam/ siang).

\section{Daftar Pustaka}

Caterpilar Tractor Co. 1981. Handbook of Earthmoving.

a CAT Publication by Caterpillar Inc., Peoria, Illinois, USA - Caterpillar Performance Haindbook. October 1988.

Ir. Imam Soekoto. Mempersiapkan Dasar Konstruksi. Departemen Pekerjaan Umum, Badan Penerbit Pekerjaan Umum 1984. 